\title{
SUPERVISI AKADEMIK BERKELANJUTAN UNTUK MENINGKATKAN KOMPETENSI PEDAGOGIK GURU DALAM MENYUSUN RENCANA PELAKSANAAN PEMBELAJARAN
}

\author{
Sukasman \\ SMP Negeri 1 Sungai Kakap, Jalan Raya Sungai Kakap, Kecamatan Sungai Kakap, \\ Kabupaten Kubu Raya, Provinsi Kalimantan Barat \\ e-mail: sk@smpn1sungaikakap.sch.id
}

\begin{abstract}
Abstrak
Tujuan penelitian untuk menganalisis supervisi berkelanjutan yang dapat meningkatkan kompetensi pedagogik guru dalam menyusun Rencana Pelaksanaan Pembelajaran (RPP). Metode penelitian menggunakan Penelitian Tindakan Sekolah (PTS). Penelitian dilakukan di SMP Negeri 8 Sungai Kakap dengan subjek penelitian yaitu para guru. Instrumen penelitian menggunakan studi dokumentasi, observasi, dan wawancara. Teknik analisis data menggunakan analisis deskriptif. Berdasarkan hasil penelitian, terlihat bahwa supervisi secara berkelanjutan terbukti secara ilmiah dapat meningkatkan kompetensi pedagogik guru dalam menyusun RPP di SMP Negeri 8 Sungai Kakap.
\end{abstract}

Kata Kunci: supervisi akademik, Rencana Pelaksanaan Pembelajaran, kompetensi pedagogik guru.

\begin{abstract}
The purpose of the research was to analyzing ongoing supervision can improve teachers pedagogic competency of in preparing the learning implementation plan. The research method used School Action Research (SAR). The study was conducted at SMP Negeri 8 Sungai Kakap with the teachers as the research subjects. The research instrument used the study of documentation, observation, and interviews. Data analysis techniques using descriptive analysis. Based on the results of the study, it appears that ongoing supervision is scientifically proven to be able to improve the pedagogic competence of teachers in preparing RPP in SMP Negeri 8 Sungai Kakap.
\end{abstract}

Keywords: academic supervision, Learning Implementation Plan, teachers pedagogic competency.

\section{PENDAHULUAN}

Perencanaan program berfungsi untuk memberikan arah pelaksanaan pembelajaran sehingga menjadi terarah dan efisien. Salah satu bagian dari perencanaan pembelajaran yang sangat penting dibuat oleh guru sebagai pengarah pembelajaran adalah silabus dan Rencana Pelaksanaan Pembelajaran (RPP). Silabus memberikan arah tentang metode dan media apa saja yang harus digunakan untuk mencapai tujuan pembelajaran. Selain itu silabus juga memuat teknik penilaian seperti apa untuk menguji sejauh mana keberhasilan 
pembelajaran. Rencana Pelaksanaan Pembelajaran (RPP) adalah instrumen perencanaan yang lebih spesifik dari silabus. Rencana Pelaksanaan Pembelajaran ini dibuat untuk memandu guru dalam mengajar agar tidak melebar jauh dari tujuan pembelajaran. Dengan melihat pentingnya penyusunan perencanaan pembelajaran ini, guru semestinya tidak mengajar tanpa adanya rencana.

Perencanaan pembelajaran yang mestinya dapat diukur, banyak yang direncanakan dalam pikiran sang guru saja atau hanya untuk melengkapi administrasi guru saja sehingga RPP yang dimiliki merupakan jiplakan dari orang lain atau hasil download internet tanpa diadaptasi lagi sesuai dengan pembelajaran guru yang bersangkutan. Akibatnya kepala sekolah sebagai pembuat kebijakan di sekolah tidak dapat mengevaluasi kinerja guru secara profesional. Kinerja yang dapat dilihat oleh kepala sekolah hanyalah kehadiran tatap muka, tanpa mengetahui apakah kemampuan guru dalam mengelola pembelajaran sudah sesuai dengan harapan atau belum, atau sudahkah kompetensi dasar yang harus dikuasai oleh siswa terkuasai dengan benar.

Kompetensi adalah kemampuan atau kecakapan (Syah, 2000). Kompentensi berarti suatu hal yang menggambarkan kualifikasi atau kemampuan seseorang, baik yang kualitatif maupun yang kuantitatif (Usman, 1994). Kompetensi diartikan sebagai pengetahuan, keterampilan, dan kemampuan yang dikuasai oleh seseorang yang telah menjadi bagian dari dirinya, sehingga dapat melakukan perilaku-perilaku kognitif, afektif, dan psikomotorik dengan sebaik-baiknya (McAhsan dalam Mulyasa, 2003). Kompetensi tidak hanya mengandung pengetahuan, keterampilan, dan sikap, namun yang penting adalah penerapan dari pengetahuan, keterampilan, dan sikap yang diperlukan tersebut dalam pekerjaan (Sofo, 1999). Kompetensi sebagai ability, yaitu kapasitas seseorang individu untuk mengerjakan berbagai tugas dalam suatu pekerjaan (Robbins, 2001). mengatakan Kompetensi adalah karakteristik mendasar dari individu yang secara kausal terkait dengan kriteria-rujukan efektif dan / atau kinerja superior dalam suatu pekerjaan atau situasi (Spencer and Spencer, 1993).

Kompetensi penyusunan rencana pembelajaran meliputi: (1) Mampu mendeskripsikan tujuan; (2) Mampu memilih materi; (3) Mampu mengorganisir 
materi; (4) Mampu menentukan metode/strategi pembelajaran; (5) Mampu menentukan sumber belajar/media/alat peraga pembelajaran; (6) Mampu menyusun perangkat penilaian; (7) Mampu menentukan teknik penilaian; dan (8) Mampu mengalokasikan waktu (Depdiknas, 2004).

Menurut Undang-Undang Nomor 14 Tahun 2005 tentang Guru dan Dosen Pasal 10 Ayat 1, kompetensi guru meliputi kompetensi pedagogik, kompetensi kepribadian, kompetensi sosial, dan kompetensi profesional yang diperoleh melalui pendidikan profesi. Penelitian yang dilakukan, berfokus pada supervisi kompetensi pedagogik. Kompetensi pedagogik merupakan kompetensi pengelolaan pembelajaran yang dapat dilihat dari kemampuan merencanakan program belajar-mengajar, kemampuan melaksanakan interaksi atau mengelola proses belajar-mengajar, dan kemampuan melakukan penilaian (Depdiknas, 2004).

Berdasarkan Permendiknas Nomor 16 Tahun 2007 tentang Standar Kualifikasi Akademik dan Kompetensi Guru disebutkan bahwa kompetensi pedagogik yang dimiliki guru yaitu: (1) Menguasai karakteristik peserta didik dari aspek fisik, moral, spiritual, sosial, kultural, emosional, dan intelektual; (2) Menguasai teori belajar dan prinsip-prinsip pembelajaran yang mendidik; (3) Mengembangkan kurikulum yang terkait dengan mata pelajaran yang diampu; (4) Menyelenggarakan pembelajaran yang mendidik; (5) Memanfaatkan teknologi informasi dan komunikasi untuk kepentingan pembelajaran; (6) Memfasilitasi pengembangan potensi peserta didik untuk mengaktualisasikan berbagai potensi yang dimiliki; (7) Berkomunikasi secara efektif, empatik, dan santun dengan peserta didik; (8) Menyelenggarakan penilaian dan evaluasi proses dan hasil belajar; (9) Memanfaatkan hasil penilaian dan evaluasi untuk kepentingan pembelajaran; dan (10) Melakukan tindakan reflektif untuk peningkatan kualitas pembelajaran.

Hasil studi dokumentasi di tahun pelajaran 2015/2016 semester 1 di SMP Negeri 8 Sungai Kakap didapatkan data hanya 60\% guru yang menyusun RPP dengan lengkap. Secara kualitas, RPP yang baik baru mencapai angka 30\% dari RPP yang dibuat oleh guru. Untuk mengatasi permasalahan tersebut, peneliti yang 
berkedudukan sebagai kepala sekolah merencanakan untuk melakukan supervisi yang berkelanjutan. Diharapkan setelah kegiatan supervisi yang berkelanjutan, kuantitas guru yang menyusun RPP meningkat menjadi 90\% dan kualitas RPP yang baik menjadi $80 \%$. Perubahan perilaku guru ke arah yang lebih berkualitas akan menimbulkan perilaku belajar murid yang lebih baik.

Supervisi dapat dirumuskan sebagai berikut serangkaian usaha pemberian bantuan kepada guru dalam bentuk layanan profesional yang diberikan oleh supervisor (pengawas sekolah, kepala sekolah, dan pembina lainnya) guna meningkatkan mutu proses dan hasil belajar mengajar. Karena supervisi atau pembinaan guru tersebut lebih menekankan pada pembinaan guru, maka terdapa istilah "Pembinaan profesional guru" yakni pembinaan yang lebih diarahkan pada upaya memperbaiki dan meningkatkan kemampuan profesional guru. Secara umum kegiatan supervisi dapat dibedakan dalam dua macam, yaitu supervisi umum dan supervisi akademik. Supervisi umum dilakukan untuk seluruh kegiatan teknis administrasi sekolah, sedangkan supervisi akademik lebih diarahkan pada peningkatan kualitas pembelajaran. Penelitian yang dilakukan berfokus pada supervisi akademik karena berkaitan dengan penyusunan perangkat perencanaan pembelajaran yang dibuat oleh guru.

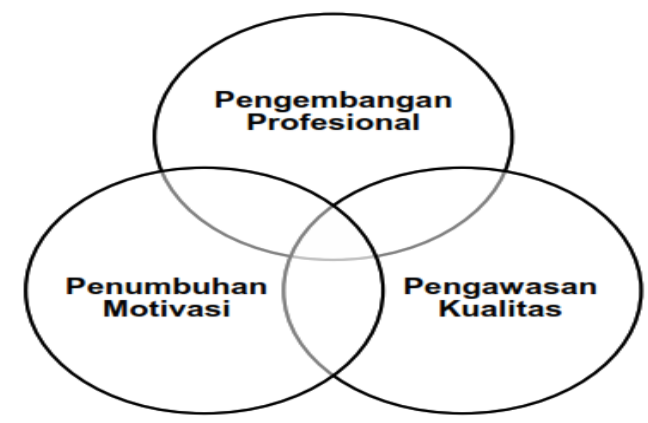

Gambar 1 Tiga Tujuan Supervisi Akademik yang Utuh

Tujuan supervisi adalah: (1) Membantu guru mengembangkan kompetensinya; (2) Mengembangkan kurikulum; dan (3) Mengembangkan kelompok kerja guru dan membimbing penelitian tindakan kelas (Glickman, 2007; Sergiovanni, 1987). Supervisi akademik yang baik adalah supervisi akademik yang mampu berfungsi mencapai tujuan tersebut. Tidak ada keberhasilan bagi supervisi akademik jika hanya memperhatikan salah satu tujuan tertentu 
dengan mengesampingkan tujuan lainnya. Hanya dengan merefleksi ketiga tujuan inilah supervisi akademik akan berfungsi mengubah perilaku mengajar guru (Alfonso, et al., 1981).

Menurut Direktorat Jenderal Peningkatan Mutu Pendidik dan Tenaga Kependidikan Kementerian Pendidikan Nasional (2016), prinsip-prinsip supervisi akademik adalah: (1) Praktis, artinya mudah dikerjakan sesuai kondisi sekolah; (2) Sistematis, artinya dikembangkan sesuai perencanaan program supervise yang matang dan tujuan pembelajaran; (3) Objektif, artinya masukan sesuai aspekaspek instrumen; (4) Realistis, artinya berdasrkan kenyataan sebenarnya; (5) Antisipatif, artinya mampu menghadapi masalah-maslaha yang mungkin akan terjadi; (6) Konstruktif, artinya mengembangkan kreativitas dan inovasi guru dalam mengembangkan pembelajaran; dan (7) Kooperatif, artinya ada kerja sama yang baik antara supervisor dan guru dalam mengembangkan pembelajaran.

Berdasarkan penjelasan yang telah diuraikan tersebut, maka tujuan penelitian adalah menganalisis supervisi berkelanjutan yang dapat meningkatkan kompetensi pedagogik guru dalam menyusun RPP.

\section{METODE}

Penelitian dilakukan di SMP Negeri 8 Sungai Kakap yang beralamat di Jalan Tanjung Darat, Desa Jeruju Besar, Kecamatan Sungai Kakap, Kabupaten Kubu Raya. Jenis penelitian merupakan Penelitian Tindakan Sekolah (PTS) menggunakan pendekatan penelitian tindakan dengan model siklus. Subjek penelitian adalah 15 orang guru di SMP Negeri 8 Sungai Kakap Kecamatan Sungai Kakap, Kabupaten Kubu Raya. Penelitian dilakukan dalam dua siklus, yang setiap siklus terdapat tahapan-tahapan berupa planning (perencanaan), acting (pelaksanaan tindakan), observing (observasi), dan reflecting (refleksi).

Setelah satu siklus selesai diimplementasikan, maka dilakukan refleksi kelebihan dan kekurangan selama pelaksanaan supervisi, kemudian dilakukan perencaaan perbaikan kedua sampai target yang diingikan tercapai. Teknik pengumpulan data yang digunakan meliputi studi dokumentasi, observasi, dan 
wawancara. Teknik analisis data yang diunakan dalam penelitian adalah analisis deskriptif.

\section{HASIL DAN PEMBAHASAN}

Perolehan data hasil penelitian dalam penyusunan Rencana Pelaksanaan Pembelajaran (RPP) dari subjek penelitian yang telah mengumpulkan RPP dan yang akan dikoreksi terlihat pada Tabel 1 dan Tabel 2.

\section{Tabel 1 Rekapitulasi Guru yang Menyerahkan Perangkat Pembelajaran} Sebelum Penelitian

\begin{tabular}{|c|c|c|c|}
\hline Komponen & $\begin{array}{l}\text { Jumlah yang } \\
\text { Seharusnya }\end{array}$ & $\begin{array}{c}\text { Jumlah yang } \\
\text { Mengumpulkan }\end{array}$ & $\begin{array}{c}\text { \% yang } \\
\text { Mengumpulkan }\end{array}$ \\
\hline $\begin{array}{l}\text { Agenda Kegiatan Harian Guru } \\
\text { a. Pemetaan Kegiatan Tugas } \\
\text { dalam Proses Pembelajaran }\end{array}$ & $\begin{array}{c}88 \\
(8 \text { rombel x 11mp) }\end{array}$ & 0 & 0 \\
\hline b. Kalender Pendidikan & 15 & 15 & 100 \\
\hline c. Daftar hadir siswa & 15 & 15 & 100 \\
\hline $\begin{array}{l}\text { d. Jurnal kegiatan } \\
\text { pembelajaran dan penilaian } \\
\text { sikap dalam pembelajaran }\end{array}$ & $\begin{array}{c}88 \\
(8 \text { rombel x 11mp) }\end{array}$ & 0 & 0 \\
\hline $\begin{array}{l}\text { e. Dafar nilai tugas terstruktur } \\
\text { dan tidak terstruktur }\end{array}$ & $\begin{array}{c}88 \\
\text { (8 rombel x } 11\end{array}$ & 0 & 0 \\
\hline f. Bukti fisik program remidial & 88 & 40 & 45 \\
\hline $\begin{array}{l}\text { g. Bukti fisik program } \\
\text { pengayaan }\end{array}$ & $\begin{array}{l}\text { (8 rombel x } 11 \\
88 \\
(8 \text { rombel x } 11\end{array}$ & 0 & 0 \\
\hline h. Rekapitulasi Nilai & $\begin{array}{l}88 \\
\text { (8 rombel x } 11\end{array}$ & 88 & 100 \\
\hline Program Tahunan & $11 \mathrm{mp} \times 3 \mathrm{kls}=33$ & 20 & 60,6 \\
\hline Program semester & $11 \mathrm{mp} \times 3 \mathrm{kls}=33$ & 20 & 60,6 \\
\hline KKM & $11 \mathrm{mp} \times 3 \mathrm{kls}=33$ & 20 & 60,6 \\
\hline Análisis pemetaan SK/KD & $11 \mathrm{mp} \times 3 \mathrm{kls}=33$ & 20 & 60,6 \\
\hline Rencana Pelaksanaan Pelajaran & $11 \mathrm{mp} \times 3 \mathrm{kls}=33$ & 20 & 60,6 \\
\hline RPP & $11 \mathrm{mp} \times 3 \mathrm{kls}=33$ & 20 & 60,6 \\
\hline Análisis Hasil Ulangan harian & $11 \mathrm{mp} \times 3 \mathrm{kls}=33$ & 0 & 0 \\
\hline Analisis hasil UTS & $11 \mathrm{mp} \times 3 \mathrm{kls}=33$ & 15 & 45,5 \\
\hline
\end{tabular}


Tabel 2 Rekapitulasi Penilaian Rencana Pelaksanaan Pembelajaran

\begin{tabular}{|c|c|c|c|c|c|c|c|}
\hline \multicolumn{2}{|c|}{ Kategori RPP } & \multicolumn{2}{|c|}{ PRASIKLUS } & \multicolumn{2}{|c|}{ SIKLUS 1} & \multicolumn{2}{|c|}{ SIKLUS 2} \\
\hline $\begin{array}{l}\text { Klasifikasi } \\
\text { Penilaian }\end{array}$ & Rentang Nilai & f & $\%$ & $\mathbf{f}$ & $\%$ & $\mathbf{f}$ & $\%$ \\
\hline$A=$ Baik sekali & $86-100$ & - & - & 1 & 6,67 & 3 & 20,00 \\
\hline B = Baik & $71-85$ & - & - & 6 & 40,00 & 10 & 66,67 \\
\hline $\mathrm{C}=$ Cukup & $51-70$ & 4 & 26,67 & 8 & 53,33 & 2 & 13,33 \\
\hline $\mathrm{D}=$ Kurang & $0-50$ & 11 & 73,33 & - & - & - & - \\
\hline \multicolumn{2}{|c|}{ Jumlah } & 15 & 100 & 15 & 100 & 15 & 100 \\
\hline
\end{tabular}

Berdasarkan Tabel 2, terlihat bahwa kesadaran guru dalam menyusun perangkat pembelajaran sebelum penelitian (prasiklus) berada pada kategori "Cukup" dan "Kurang", kemudian meningkat setelah dilakukan supervisi pertama (siklus 1) dengan kategori terbesar adalah "Cukup". Setelah dibimbing dan diberikan penguatan untuk diadakan supervisi kedua (siklus 2) meningkat dengan kategori terbesar adalah "Baik". Hal tersebut berarti guru sudah menyusun dan mengumpulkan RPP kepada kepala sekolah untuk dikoreksi dan jumlahnya meningkat dari prasiklus, siklus 1, dan siklus 2 (Rosilawati, 2014; Hamid, 2017).

Setelah dokumen RPP ditelaah secara keseluruhan yang sudah terkumpul peneliti menelaah kualitas kandungan RPP dan diperoleh data bahwa kualitas RPP yang dibuat oleh guru SMP Negeri 8 Sungai Kakap secara umum masih kurang baik. Berikut data hasil penilaian terhadap kualitas RPP 15 orang guru SMP Negeri 8 Sungai Kakap tahun pelajaran 2015/2016 semester 1.

Tabel 3 Hasil Uji Keaslian Rencana Pelaksanaan Pembelajaaran

\begin{tabular}{cccccccc}
\hline \multicolumn{2}{c}{ Kategori RPP } & \multicolumn{2}{c}{ PRASIKLUS } & \multicolumn{2}{c}{ SIKLUS 1 } & \multicolumn{2}{c}{ SIKLUS 2 } \\
\hline Klasifikasi Penilaian & Rentang Nilai & f & \% & f & \% & f & \% \\
\hline A = Sesuai & $86-100$ & 0 & 0,00 & 8 & 53,33 & 12 & 80,00 \\
B = Cukup sesuai & $76-85$ & 4 & 26,67 & 4 & 26,67 & 3 & 20,00 \\
C = Kurang sesuai & $51-75$ & 11 & 73,33 & 3 & 20,00 & - & - \\
D = Tidak sesuai & $0-50$ & & & - & - & - & - \\
\hline Jumlah & & & $\mathbf{1 0 0}$ & $\mathbf{1 5}$ & $\mathbf{1 0 0}$ & $\mathbf{1 5}$ & $\mathbf{1 0 0}$ \\
\hline
\end{tabular}

Berdasarkan kualitas RPP yang diserahkan guru setelah peneliti telaah dan berikan skor atau peniliaan sesuai dengan tata urutan penyusunan Rencana Pelaksanaan Pembelajaran yang mendapatkan skor amat baik pada saat pra siklus 
belum ada, skor baik 4 orang dan yang lainnya masih belum mencapai kriteria yang ditentukan yaitu baik. Setelah silakukan pembinaan selama dua siklus terjadi kenaikan kualitas dari RPP yang dibuat guru dimana pada siklus pertama kategori A ada 53,33\% RPP yang dikumpulkan telah mencapai kategori B 26,67\%, dan sisa masih dalam kategori C sebanyak 20\%. Pada siklus kedua setelah diadakan pembinaan tentang tata cara penyusunan RPP, maka diperoleh hasil yang RPP tersebut dinyatakan kualitasnya dalam kategori A ada $80 \%$ dan yang termassuk kategori B ada 20\% dalam hal ini RPP yang disusun oleh guru sudah temasuk sesuai dengan standar. Supervisi akademik merupakan serangkaian kegiatan yang dapat membantu guru dalam mengembangkan kemampuannya untuk mengelola proses pembelajaran sehingga dapat meningkatkan kompetensi pedagogik, yang muaranya kepada peningkatan mutu lulusan peserta didik (Okendu, 2012; Adewale, 2014; Ambarita, dkk., 2014; Usman, 2015; Arman, 2016; Hartanto dan Purwanto, 2016; Gratrix dan Barrett, 2017).

Kegiatan supervisi akademik berkelanjutan yang dilakukan oleh kepala sekolah kepada guru dengan tujuan memberikan bantuan profesional. Selain itu supervisi akademik berkelanjutan juga bertujuan untuk meningkatkan kompetensi pedagogik yang akan berdampak pada peningkatan kinerja guru-guru di sekolah (Ambarwangi dan Rachman, 2015; Astuti, 2016; Damayanti, 2016; Mudzakir, 2016; Ndapaloka, dkk., 2016; Hardono, dkk., 2017; Leniwati dan Arafat, 2017, Irawan, dkk., 2018; Prasetyono, dkk., 2018). Berdasarkan Permendiknas Nomor 41 Tahun 2007 dinyatakan bahwa perencanaan proses pembelajaran meliputi silabus dan rencana pelaksanaan pembelajaran (RPP) yang memuat identitas mata pelajaran, standar kompetensi (SK), kompetensi dasar (KD), indikator pencapaian kompetensi, tujuan pembelajaran, materi ajar, alokasi waktu, metode pembelajaran, kegiatan pembelajaran, penilaian hasil belajar, dan sumber belajar.

\section{SIMPULAN}

Berdasarkan hasil analisis data hasil supervisi Rencana Pelaksanaan Pembelajaran yang disusun guru SMP Negeri 8 Sungai Kakap dapat disimpulkan bahwa supervisi secara berkelanjutan terbukti secara ilmiah dapat meningkatkan 
kompetensi pedagogik guru dalam menyusun RPP di SMP Negeri 8 Sungai Kakap. Ini terbukti dengan meningkatnya hasil penilaian terhadap RPP dari prasiklus yang hanya 26,67\% (kategori "Cukup") menjadi 53,33\% (kategori "Cukup") setelah dilakukan supervisi pada siklus pertama dan 66,67\% (kategori "Baik") setelah dilakukan supervisi pada siklus kedua.

\section{DAFTAR PUSTAKA}

Adewale, O. S. 2014. Intructional Improvement of Secondary School Teachers through Effective Academic Supervision by the Vice-Principals. Journal of Education and Human Development, 3(2): 607-617.

Alfonso, R. J., Firth, G., \& Neville, R. 1981. Intructional Supervision a Behavioral System. Boston: Allyn Bacon.

Ambarita, B., Siburian, P., \& Purba, S. 2014. Development of Academic Supervision Model which Based on Educational Management. International Journal of Sciencies: Basic and Applied Research, 18(1): 304-314.

Ambarwangi, S. \& Rachman, M. 2015. Holistic Academic Supervision Model for Cultural Art Teachers of Vocational High School. HARMONIA: Journal of Arts Research and Education, 15(1): 62-67.

Arman, A. 2016. Upaya Peningkatan Kompetensi Guru dalam Menyusun Rencana Pelaksanaan Pembelajaran melalui Supervisi Akademik Kepala Sekolah di SMAN 1 Lembah Melintang Kabupaten Pasaman Barat. Jurnal Manajemen Pendidikan, 1(1): 55-61.

Astuti, S. 2016. Penerapan Supervisi Akademik untuk Meningkatkan Kompetensi Guru dalam Menyusun Administrasi Penilaian di SD Laboratorium UKSW. Scholaria, 6(1): 117-126.

Damayanti, W. 2016. Peningkatan Mutu Kinerja Guru melalui Supervisi Akademik di SMK Negeri 1 Salatiga Menghadapi PKG 2016 (Solusi Perubahan dengan Gabungan Model Supervisi Akademik Artistic Model dan Cooperative Development Model. Jurnal Pendidikan Ilmu Sosial, 26(1): 80-86.

Depdiknas. 2007. Supervisi Akademik; Materi Pelatihan Penguatan Kemampuan Kepala Sekolah; Jakarta: Depdiknas.

Depdiknas. 2004. Petunjuk Pengelolaan Adminstrasi Sekolah Dasar. Jakarta: Depdiknas.

Gratrix, L. \& Barrett, D. 2017. Desperately Seeking Consistency: Students Nurses' Experiences and Expectations of Academic Supervision. Nurse Education Today, 48(2017): 7-12. 
Glickman, C. 2002. Leadership For Learning : How To Help Teachers Succeed. Association for Supervision and Curriculum Development. Alexandria, Virginia USA.

Hamid, A. 2017. Upaya Peningkatan Kompetensi Guru dalam Menyusun Perangkat Pembelajaran melalui Supervisi Akademik yang Berkelanjutan SDN 007 Panipahan Darat. Jurnal PAJAR (Pendidikan dan Pengajaran), 1(2): 277-289.

Hardono, Haryono, \& Yusuf, A. 2017. Kepemimpinan Kepala Sekolah, Supervisi Akademik, dan Motivasi Kerja dalam Meningkatkan Kinerja Guru. Educational Management, 6(1): 26-33.

Hartanto, S. \& Purwanto, S. 2016. Supervisi dan Penilaian Kinerja Guru. Jakarta: Direktorat Jenderal Guru dan Tenaga Kependidikan.

Irawan, D., Wahyudin, A., \& Yanto, H. 2018. The Moderating Influence of the Acedemic of Teacher Competencies and Comitment towards Organizational of Teacher Performance. Educational Management, 7(1): 65-70.

Leniwati \& Arafat, Y. 2017. Implementasi Supervisi Akademik Kepala Sekolah untuk Meningkatkan Kinerja Guru. Jurnal Manajemen, Kepemimpinan, dan Supervisi Pendidikan, 2(1): 106-114.

Mudzakir, D. 2016. Implementasi Supervisi Manajerial dan Akademik Pengawas dalam Meningkatkan Kinerja Guru Pendidikan Agama Islam Madrasah Ibtidayah. STUDIA DIDKATIKA Jurnal Ilmiah Pendidikan, 10(2): 33-47.

Mulyasa, E. 2003. Kurikulum Berbasis Kompetensi: Konsep, Karakteristik, dan Implementasi. Bandung: PT Remaja Rosdakarya.

Ndapaloka, V., Hardyanto, W., \& Prihatin, T. 2016. Pengaruh Supervisi Akademik Pengawas dan Kepemimpinan Kepala Sekolah melalui Motivasi Berprestasi sebagai Mediasi terhadap Kinerja Guru SMK Negeri Kabupaten Ende. Educational Management, 5(1): 42-54.

Okendu, J. N. 2012. The Influence of Instructional Process and Supervision on Academic Performance of Secondary School Students of Rivers State, Nigeria. Academic Research International, 3(1): 332-338.

Permendiknas Nomor 16 Tahun 2007 tentang Standar Kualifikasi Akademik dan Kompetensi Guru.

Permendiknas 41 Tahun 2007 tentang Standar Proses.

Prasetyono, H., Abdillah, A., \& Fitria, D. 2018. Academic Supervision toward Teacher's Performance through Motivation as Intervening Variable. Journal of Education and Learning, 12(2): 188-197.

Robbins, S. P. 2001. Organizational Behavior. New Jersey: Pearson Education International. 
Rosilawati, T. 2014. Supervisi Akademik dalam Upaya Peningkatan Motivasi

Guru Menyusun Perangkat Persiapan Pembelajaran. Jurnal Penelitian Tindakan Sekolah dan Kepengawasan, 1(2): 57-62.

Spencer, L. M. \& Spencer, S. M. 1993. Competence at Work: Models for Superior Performance. John Wiley \& Sons. Inc.

Sofo, F. 1999. Human Resource Development, Perspective, Roles and Practice Choice. Warriewood, NWS: Business and Professional Publishing.

Syah, M. 2000. Psikologi Pendidikan dengan Pendekatan Baru. Bandung: PT Remaja Rosdakarya.

Undang- Undang Nomor 14 Tahun 2015 tentang Guru dan Dosen.

Usman, M. U. 1994. Menjadi Guru Profesional. Bandung: PT Remaja Rosdakarya.

Usman, Y. D. 2015. The Impact of Instructional Supervision on Academic Performance of Secondary School Students in Nasarawa State, Nigeria. Journal of Education and Practice, 6(10): 160-167. 